\title{
In vitro assay on homeopathic solutions on Metarhizium anisopliae (Metsch) Sorok (Ascomycota: Clavicipitaceae)
}

\author{
Efeito in vitro de soluções homeopáticas sobre Metarhizium anisopliae \\ (Metsch) Sorok (Ascomycota: Clavicipitaceae)
}

\author{
Silvana Damin ${ }^{1 *}$, Luis Francisco Angeli Alves ${ }^{1}$, Andreia Kusumota Bonini ${ }^{1}$, Talita Moretto Alexandre ${ }^{1}$

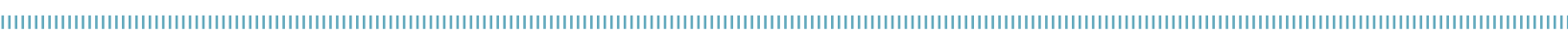

RESUMO: O presente trabalho teve por objetivo avaliar o efeito in vitro das soluçóes homeopáticas Arsenicum album 24CH; Calcarea carbonica 30CH; Kali iodatum 100CH; Phosphorus 3CH; Silicea $30 \mathrm{CH}$; Staphysagria 6, 30 e 100CH; Spodoptera frugiperda 30CH; Sulphur 100 e 200CH e Thuya occidentalis 200CH sobre parâmetros biológicos do fungo Metarhizium anisopliae. As soluçóes medicamentosas foram diluídas em água destilada (esterilizada) $(0,1 \%)$ e pulverizadas sobre o fungo previamente inoculado no meio de cultura BDA. Os parâmetros biológicos avaliados foram: germinação de conídios, unidades formadoras de colônias, crescimento vegetativo, produção de conídios e atividade inseticida contra lagartas de Diatraea saccharalis (Lepidoptera: Crambidae). As soluçóes não afetaram os parâmetros avaliados. Todos os tratamentos foram considerados compatíveis ao $M$. anisopliae.

PALAVRAS-CHAVE: fungos entomopatogênicos; soluções dinamizadas; conservação de espécies; compatibilidade.
ABSTRACT: This study aimed to evaluate the in vitro effect of homeopathic solutions Arsenicum Album 24CH; Calcarea carbonica 30CH; Kali iodatum 100CH; Phosphorus 3CH; Silicea 30CH; Staphysagria 6, 30 and 100CH; Spodoptera frugiperda $30 \mathrm{CH}$; Sulphur 100 and $200 \mathrm{CH}$ and Thuya occidentalis $200 \mathrm{CH}$ on biological parameters of the fungus Metarhizium anisopliae. The solutions were diluted in sterile distilled water $(0.1 \%)$ and were sprayed on the previously inoculated fungus on PDA culture medium. Germination, colony forming units, vegetative growth, conidial production and insecticidal activity of the fungus against larvae of Diatraea saccharalis (Lepidoptera: Crambidae) were evaluated. Homeopathic solutions did not affect negatively the parameters evaluated. Thus, all treatments were considered compatible to the fungus $M$. anisopliae.

KEYWORDS: entomopathogenic fungus; dynamized solution; species conservation; compatibility. 


\section{INTRODUCTION}

The entomopathogenic fungi have great potential in pest control, due to its capacity to suppress insect populations in all stages of host development (Leite et al., 2003). They are the major microbial agents controlling insect pests. Around $80 \%$ of diseases in insects have entomopathogenic fungi as etiologic agent (Alves, 1998).

The fungus Metarhizium anisopliae (Metsch.) Sorok. stands out as a natural pathogen of several agricultural pests, being recommended in Brazil to control sugarcane froghopper (Mahanarva fimbriolata and M. posticata), pasture spittlebugs (Notozulia entreriana, Deois flavopicta, D. incompleta, D. schach, Aeneolamia selecta), sugarcane borer (Diatraea saccharalis) and locusts (Rhammatocerus schistocercoides) (Alves et al., 2010; Brasil, 2013).

Products based on $M$. anisopliae represented about 30\% of the market mycoinsecticides in the Latin America in 2007/2008 (Faria; Wraight, 2007; Alves; Lopes, 2008). However, when considered in addition to the products available, the products under registration process, these represented 55\% of the market in 2009 (Michereff Filho et al., 2009).

This growth mainly comes from organic or agroecological farmers who have opted for alternative practices such as the use of natural pesticides (NP) in pest control. Out of which, the products based on microorganisms, especially bacteria and fungi, protective mixtures (Bordeaux mixture, Viçosa mixture, and lime sulfur), plant extracts, essential oils and homeopathic products are included.

Among the products taken as alternative, those homeopathic are the latest in agricultural use. In Brazil, the first reports were described by Brunini; Arenales (1993) who used Staphysagria in vegetables and ornamental plants, resulting in increased plant resistance to aphids, as well as improvement in the general conditions of plants. In recent years, several studies demonstrate the potential of homeopathic products for control and insect repellence (Almeida et al., 2003), phytopathogens control (Phakopsora euvitis Ono and Alternaria solani Ellis \& Martin) (Bonato et al., 2006; Toledo, 2009, Modolon, 2010), induction resistance in plant, increase both secondary metabolites production and plant productivity (CAstro et al., 2002; DuArte, 2007).

Commonly used in farms based on agroecological techniques, the NP are considered safe and healthy for agricultural production, and selective to natural enemies (Alves et al., 1998a). For Alves; Lopes (2008), preservation of microorganisms in the soil is of great importance, since they are components of a sustainable system of pest control, and, in case of positive associations of biological agents with synthetic pesticides (SP) or NP and other control techniques, higher productivity and healthier foods can be obtained.

By the practical, economical and sustainable peculiarities, NPs have received special attention in studies to evaluate their efficiency, their mode of action and action on biological control agents. Accordingly, it was found that some commercial products such as Ecolife ${ }^{\bullet}$ and Stubble-Aid ${ }^{\circledR}$ and others neem-oil-based affected conidia production and the vegetative growth of M. anisopliae (MARQues et al., 2004; Formentini et al., 2013). Mamprim et al. (2013) highlighted the negative effect of lime sulfur broth on all biological parameters of $M$. anisopliae, classified as moderately toxic. However, the same authors have shown that aqueous and alcoholic plant extracts of some insecticide plants have proved compatible to the fungal development.

The entomopathogenic microorganisms can be considered in the agroecosystem under two aspects, whether natural or a component of microbial product (biopesticide), and, thus, the studies to understand the interaction between them and NP are justified (Rossi-ZaLAF et al., 2008).

Regarding the homeopathy action on microorganisms, the few existing studies seek to control the phytopathogens, with inhibition of spore germination of Fusarium roseum (Khanna; Chandra, 1976), reduced mycelial growth and sporulation of Alternaria solani submitted to homeopathic treatments (Toledo, 2009; Modolon, 2010).

The evidence of these early studies on the action of homeopathic products on phytopathogenic fungi alert for possible interactions with entomopathogenic fungi also demonstrating the need for evaluating homeopathic remedies for such biological agents.

Thus, the present study aimed at evaluating the effect of homeopathic medicines recommended for various agricultural purposes on the fungus $M$. anisopliae.

\section{MATERIAL AND METHODS}

\section{Fungal isolate and homeopathic medicines}

The fungus Metarhizium anisopliae (strain UNIOESTE 22) from the Collection of Entomopathogenic Fungi UNIOESTE was cultured on potato-dextrose-agar (PDA) plates, and conidia were produced by subculturing the fungus on a sporulation medium (SM) containing $0.36 \mathrm{~g} \mathrm{KH}_{2} \mathrm{PO}_{4}, 1.05 \mathrm{~g}$ $\mathrm{Na}_{2} \mathrm{HPO}_{4} \cdot 7 \mathrm{H}_{2} \mathrm{O}, 0.6 \mathrm{~g} \mathrm{MgSO} \cdot 7 \mathrm{H}_{2} \mathrm{O}, 1 \mathrm{~g} \mathrm{KCl}, 10 \mathrm{~g}$ glucose, $1.58 \mathrm{~g} \mathrm{NaNO}_{3}, 5 \mathrm{~g}$ yeast extract, and $20 \mathrm{~g}$ agar in $1,000 \mathrm{~mL}$ water, incubated at $26^{\circ} \mathrm{C}$ and $12 \mathrm{~h}$ photoperiod for growth and spore production for 8 days. The conidia were collected by scraping the medium surface, transferred to sterile glass tubes, stored at $-10^{\circ} \mathrm{C}$ for a period not exceeding 10 days until performing the experiments.

The homeopathic products Arsenicum album 24CH; Calcarea carbonica 30CH; Kali iodatum 100CH; Phosphorus 3CH; Silicea 30CH; Staphysagria 6, 30 and 100CH; Spodoptera 
frugiperda 30CH; Sulphur 100 and $200 \mathrm{CH}$; and Thuya occidentalis $200 \mathrm{CH}$ were evaluated, whose selection was based on the results of scientific studies on the effects of these drugs on various plant species, insects and microorganisms (Table 1). The preparation of drugs was performed in homeopathic pharmaceutical laboratory based in the Farmacopeia Homeopática Brasileira (Brasil, 1997).

Thus, $0.2 \mathrm{~mL}$ of each of homeopathic solution were added separately in $19.8 \mathrm{~mL}$ (1/100 dilution) in $70 \%$ ethanol with 100 vigorous shaking or sucussion in mechanical arm dynamizer (Model 50-Autic Denise) to produce the fourth Hahnemannian centesimal dilution $(4 \mathrm{CH})$. In successive dilutions, they were obtained in the following dilutions of each drug, which were stored for later use.

Each treatment was prepared by adding $20 \mu \mathrm{L}$ of homeopathic solution to $19.98 \mathrm{ml}$ of sterile distilled water in a sterile glass tube (solution at $0.1 \%$ concentration homeopathic/ water), these treatments being then sprayed on the fungus according to each biological parameter.

\section{General procedures for in vitro evaluation}

Sterile glass tubes containing the fungus produced as described before were used, in which were added $10 \mathrm{~mL}$ of sterile distilled water + Tween $80(0.01 \%)$. The suspension was stirred, quantified in Neubauer chamber and standardized in the concentration of $1 \times 10^{9}$ conidia $\mathrm{mL}^{-1}$ with subsequent dilutions, appropriate to the evaluated parameters, namely: vegetative growth, conidial production and insecticidal activity, according to Silva; Neves (2005) and Oliveira (2009).

Conidia germination - The PDA medium (200 g potato, $20 \mathrm{~g}$ dextrose, $0.05 \mathrm{~g}$ streptomycin, $15 \mathrm{~g}$ agar and $1,000 \mathrm{~mL}$ sterile distilled water) was poured into the Rodac-type plate and after PDA medium solidification, $150 \mathrm{uL}$ fungal suspension $\left(1 \times 10^{6}\right.$ conidia $\left./ \mathrm{mL}\right)$ were inoculated on its surface, spread on with manual and circular movement of the plate. Then, $150 \mu \mathrm{L}$ of each of homeopathic solutions sprayed with a micro-sprayer coupled to an air compressor (constant pressure of $0.84 \mathrm{kgf} / \mathrm{cm}^{2}$ output). The control plates received the spraying of $150 \mu \mathrm{L}$ sterile distilled water + Tween ${ }^{\circ} 80(0.01 \%)$. For each treatment, five plates were prepared, each one corresponding to a repetition. All plates were incubated for $18 \mathrm{~h}$ at $26 \pm 1^{\circ} \mathrm{C}$ and $12 \mathrm{~h}$ photoperiod.

After incubation, the conidia were counted under optical microscope ( $400 \times$ magnification) by dividing each dish into four quadrants and counting at least 100 conidia per quadrant, thus quantifying germinated and non-germinated conidia.

Colony forming units (CFU) $-100 \mu \mathrm{L}$ of a fungal suspension $\left(1 \times 10^{3} \mathrm{conidia} / \mathrm{mL}\right)$ were inoculated and distributed on the surface of PDA culture medium in Petri dish with a Drigalski loop. Then, $100 \mu \mathrm{L}$ of treatments were sprayed on the inoculated fungus. In the control, plates containing fungus received $100 \mu \mathrm{L}$ sterile distilled water + Tween ${ }^{\ominus} 80(0.01 \%)$. The plates were incubated for three days at $26 \pm 1^{\circ} \mathrm{C}$ and $12 \mathrm{~h}$ photoperiod with subsequent quantification of colonies formed. Five plates were prepared for all treatments, each of them considered as a repetition.

Vegetative growth - The fungus was inoculated on the culture medium surface in a Petri dish with a platinum loop at three points. The plates were incubated at $26 \pm 1{ }^{\circ} \mathrm{C}$ and $12 \mathrm{~h}$ photoperiod for 2 days. After incubation, $250 \mu \mathrm{L}$ treatment/ plate were sprayed. The control plates were treated with sterile distilled water + Tween $80(0.01 \%)$ onto culture media surface. Plates were again incubated for five days under the same conditions described above. The vegetative growth was determined

Table 1. Homeopathic medicines used with respective dilutions, mode of action and indications from the literature.

\begin{tabular}{|c|c|c|c|}
\hline Treatments & Dilution & Mode of action/ Indication & References \\
\hline Arsenicum album & $24 \mathrm{CH}$ & $\begin{array}{l}\text { Production of secondary metabolites, control of } \\
\text { phytopathogens, soil detoxification and plants }\end{array}$ & CASALI et al., 2009; BonAto et al., 2012; \\
\hline Calcarea carbonica & $30 \mathrm{CH}$ & $\begin{array}{l}\text { Vegetative growth in plants, soil with } \\
\text { calcium deficiency }\end{array}$ & BonATO et al., 2012 \\
\hline Kali iodatum & $100 \mathrm{CH}$ & Control of phytopathogens; plant development & $\begin{array}{l}\text { TOLEDO, 2009; CASALI et al., 2009; } \\
\text { BONATO et al., } 2012\end{array}$ \\
\hline Phosphorus & $3 \mathrm{CH}$ & $\begin{array}{l}\text { Production of secondary metabolites } \\
\text { (essential oil), control of phytopathogens }\end{array}$ & $\begin{array}{l}\text { DUARTE, 2007; CASALI et al., 2009; } \\
\text { ANDRADE, } 2000\end{array}$ \\
\hline Silicea & $30 \mathrm{CH}$ & $\begin{array}{l}\text { Control of phytopathogens and pests; } \\
\text { plant development }\end{array}$ & $\begin{array}{l}\text { BONATO et al., 2006; CASALI et al., 2009; } \\
\text { BONATO et al., } 2012\end{array}$ \\
\hline Staphysagria & $\begin{array}{l}6 ; 30 \mathrm{e} \\
100 \mathrm{CH}\end{array}$ & $\begin{array}{l}\text { Control of insects, mites and } \\
\text { phytopathogenic diseases }\end{array}$ & BONATO et al., 2012; RuPP et al., 2012; \\
\hline $\begin{array}{l}\text { Spodoptera } \\
\text { frugiperda }\end{array}$ & $30 \mathrm{CH}$ & Control of insects & ALMEIDA et al., 2003; BonATO et al., 2012 \\
\hline Sulphur & $\begin{array}{l}100 \mathrm{e} \\
2 \mathrm{OOCH}\end{array}$ & Control of phytopathogens and pests & $\begin{array}{l}\text { SINHA; SINGH (1983); BonATO et al., 2007; } \\
\text { CASALI et al., } 2009\end{array}$ \\
\hline Thuya occidentalis & $200 \mathrm{CH}$ & Control of phytopathogens, insects and mites & CASALI et al., 2009; BonATO et al., 2012 \\
\hline
\end{tabular}


based on two perpendicular measurements of the colonies with a caliper rule in order to obtain the average diameter.

Conidia production - After verification of vegetative growth, the colonies obtained previously were cut and transferred individually to sterile glass tubes, to which were added $10 \mathrm{~mL}$ of sterile distilled water + Tween $80(0.01 \%)$. After stirring for about 2 minutes, the conidia quantification was performed in Neubauer chamber and optical microscope. For each treatment, 10 colonies were evaluated, 2 of each repetition.

\section{Effect of different hydroalcoholic solutions on M. anisopliae}

Whereas homeopathic products are made of alcoholic solutions, an experiment was conducted in order to verify the effect of this solvent on the biological parameters of the fungus.

General procedures were adopted for in vitro evaluation, as previously described, having the spraying of hydroalcoholic solutions as treatments in the concentrations ranging from 0.5 to $2.5 \%$ of alcohol/distilled sterile water. The percentage values were chosen based on the recommendation for preparing the "broth" applied in the field, it should not be applied alcoholic solutions above $1 \%$, given the possibility of toxicity to plants and biological agents (Bonato et al., 2012). Sterile distilled water was applied in the control. For each treatment and also the control, five replicates were prepared.

\section{Effect of different homeopathic products on M. anisopliae}

The same experimental procedures described in the general procedures for in vitro evaluation were used, with homeopathic products at $0.1 \%$ as treatment (Table 1 ). A non-diluted $0.1 \%$ hydroalcoholic solution and a control were used, in which was applied sterile distilled water + Tween ${ }^{\oplus} 80(0.01 \%)$.

Besides the parameters previously mentioned, the effect of homeopathic products on the insecticidal activity of $M$. anisopliae was evaluated as follow.

The fungus was inoculated onto SM in Petri dishes and about one hour later they were sprayed with $250 \mu \mathrm{L}$ each of the products, using a micro-sprayer coupled to air compressor $\left(0.84 \mathrm{~kg} / \mathrm{cm}^{2}\right.$ output constant pressure). In the control plates, $250 \mu \mathrm{L}$ of sterile distilled water were applied on the fungus. The plates were incubated for 8 days at $26 \pm 1^{\circ} \mathrm{C}$ and $12 \mathrm{~h}$ photophase. The conidia were collected by scraping the medium surface and transferred to sterile glass tubes, then preparing suspensions at $1 \times 10^{9}$ conidia $/ \mathrm{mL}$, which was previously determined as one to obtain approximately $80 \%$ mortality of Diatraea saccharalis (Fabr.) (Lepidoptera: Crambidae).

Third-instar larvae of $D$. saccharalis from the laboratory rearing and fed on artificial diet were used in the bioassays (PARRA, 1999).

The insects were placed in Petri dishes and received $2 \mathrm{~mL}$ of treatments using a Potter tower $\left(1.05 \mathrm{kgf} / \mathrm{cm}^{2}\right)$. After 1 minute, the larvae were transferred to Petri dishes containing artificial diet and were incubated for 10 days at $26 \pm 1^{\circ} \mathrm{C}$ and $12 \mathrm{~h}$ photophase. Daily, the food replacement and mortality assessment were performed, with dead insects being removed, immersed in 70\% alcohol for 15 seconds and in sterile distilled water for equal time, and transferred to a moist chamber for confirming the fungus mortality, noting signs and symptoms of fungal infection as Alves et al. (1998b). For each treatment and also for the control, they were used 60 larvae divided into 4 replicates.

\section{Data analysis}

Experimental design was completely randomized set-up and the data tested for normality (Shapiro-Wilk) and analysis of variance (F-test). The means were compared by the ScottKnott test, both at $5 \%$ by using the statistical program Sisvar ${ }^{\circ}$ (FERREIRA, 2011).

The compatibility between treatments and fungus was based on the Biological Index formula (BI) proposed by Rossi-ZaLaf et al. (2008) calculated as:

$\mathrm{IB}=\frac{47[\mathrm{CV}]+43[\mathrm{ESP}]+10[\mathrm{GER}]}{100}$, where:

$\mathrm{IB}=$ Biological Index $\mathrm{CV}=$ percentage of colony's vegetative growth after 7 days, compared to the control; ESP = percentage of sporulation of colonies after 7 days compared to control; $\mathrm{GER}$ = percentage of germinated conidia, since that the CV, ESP and GER values should be previously corrected for the respective controls. The IB values $(\mathrm{p}=0.05)$ for products classification were: Toxic $-0-41$; Moderately Toxic $-42-66$; and Compatible - > 66 .

\section{RESULTS AND DISCUSSION}

\section{Effect of different hydroalcoholic solutions of M. anisopliae}

The different hydroalcoholic solutions, in general, did not affect the biological parameters of $M$. anisopliae. The viability of conidia, number of CFU and the vegetative growth were not affected by alcoholic solutions in culture medium. However, the hydroalcoholic solutions at 2.0 and $2.5 \%$ stimulated the conidia production (Table 2).

In a study on the phytopathogenic fungus Alternaria solani, diluted hydroalcoholic solutions (at $0.0015 \%$ alcohol) may have action on biological parameters of the fungus, differing from the control distilled water (Toledo, 2009).

The findings of Toledo (2009) reaffirm the potential energy of homeopathic medicines, coming from the dilution 
process (with sucussion), as the alcohol concentration used by the author in the tests was very low. Perhaps the results contrary to this study are due to the different species of fungi used in both studies.

It is noteworthy that even the hydroalcoholic solutions with double of the alcohol present in homeopathic solutions showed no negative effect, discarding any possibility of the alcohol present in homeopathic solution to interfere with the biological parameters of $M$. anisopliae.

\section{Action of homeopathic solutions on M. anisopliae}

The viability of conidia in all treatments was above 93\%, not differing significantly from the control (94\%), corroborating the observations of ToLEDo (2009), who also found no effect of homeopathic products Sulphur, Silicea terra, Staphysagria, Phosphorus and Kali iodatum on the germination of the fungus $A$. solani.

In the germination phase, both the SP and NP are more likely to intervene in the development of entomopathogenic fungi because, when sprayed, the products come into direct contact with the conidia which have not yet penetrated the insect integument at this time and may compromise the control efficiency by entomopathogen (Alves et al., 1998a; Silva et al., 2005).

There was also no effect on the CFU formation, and even the solutions Arsenicum album 24CH, Calcarea carbonica 30CH, Phosphorus 3CH, Staphysagria 6CH, Spodoptera frugiperda 30CH, Sulphur 100CH and Thuya occidentalis $200 \mathrm{CH}$ stimulated this parameter when compared with the control (Table 3).

Table 2. Viability of conidia, colony forming units, vegetative growth and production of Metarhizium anisopliae (UNIOESTE 22), subject to different alcoholic degrees $\left(26 \pm 1^{\circ} \mathrm{C}\right.$ and $12 \mathrm{~h}$ photoperiod).

\begin{tabular}{|c|c|c|c|c|}
\hline Treatments & Viability (\%) & CFU & $\begin{array}{l}\text { Vegetative } \\
\text { growth }\left(\mathrm{cm}^{2}\right)\end{array}$ & $\begin{array}{l}\text { Conidia production } \\
\qquad\left(\times 10^{6} / \mathrm{mL}\right)\end{array}$ \\
\hline Control & $97.8 \pm 1.29 a$ & $35.5 \pm 4.15 a$ & $2.0 \pm 0.23 a$ & $17.2 \pm 1.64 b$ \\
\hline $0.5 \%$ hydroalcoholic solution & $98.9 \pm 0.80 \mathrm{a}$ & $29.8 \pm 2.42 \mathrm{a}$ & $2.8 \pm 0.30 a$ & $13.9 \pm 2.13 b$ \\
\hline $1.0 \%$ hydroalcoholic solution & $98.1 \pm 0.41 \mathrm{a}$ & $29.8 \pm 3.53 a$ & $2.8 \pm 0.22 \mathrm{a}$ & $13.0 \pm 2.53 b$ \\
\hline $1.5 \%$ hydroalcoholic solution & $97.9 \pm 0.42 a$ & $29.5 \pm 2.30 \mathrm{a}$ & $3.2 \pm 0.05 a$ & $16.7 \pm 2.13 b$ \\
\hline $2.0 \%$ hydroalcoholic solution & $98.7 \pm 0.74 \mathrm{a}$ & $28.6 \pm 3.96 a$ & $3.6 \pm 0.36 a$ & $19.7 \pm 2.56 \mathrm{a}$ \\
\hline $2.5 \%$ hydroalcoholic solution & $98.4 \pm 0.96 a$ & $26.8 \pm 3.99 a$ & $3.5 \pm 0.05 a$ & $22.3 \pm 3.02 \mathrm{a}$ \\
\hline C.V. (\%) & 1.08 & 16.32 & 6.57 & 18.43 \\
\hline Factor $\mathrm{F}$ & 0.70 & 1.71 & 1.46 & 2.96 \\
\hline
\end{tabular}

Means $( \pm$ SE) followed by the same letter in the column for each product tested does not differ by the Scott-Knott test at $5 \%$ significance. CFU: colony forming units.

Table 3. Viability of conidia, colony forming units, vegetative growth, conidia production, "T" values and compatibility of Metarhizium anisopliae (UNIOESTE 22) subjected to different homeopathic medicines ( $26 \pm 1{ }^{\circ} \mathrm{C}$ and 12 -h photophase).

\begin{tabular}{|c|c|c|c|c|c|}
\hline Homeopathic drugs & Viability (\%) & CFU & $\begin{array}{c}\text { Vegetative } \\
\text { growth }\left(\mathrm{cm}^{2}\right)\end{array}$ & $\begin{array}{c}\text { Conidia } \\
\text { production } \\
\left(\times 10^{6} / \mathrm{mL}\right)\end{array}$ & $\mathrm{T} / \mathrm{C}$ value \\
\hline Control & $94.7 \pm 0.77 a$ & $39.0 \pm 2.61 b$ & $3.1 \pm 0.07 a$ & $31.7 \pm 2.13 b$ & - \\
\hline Hydroalcoholic sol. (0.1\%) & $94.8 \pm 0.94 a$ & $39.6 \pm 3.77 b$ & $3.1 \pm 0.13 a$ & $37.0 \pm 4.32 \mathrm{a}$ & - \\
\hline A. album $24 \mathrm{CH}$ & $94.0 \pm 1.53 \mathrm{a}$ & $52.6 \pm 2.78 a$ & $3.0 \pm 0.20 \mathrm{a}$ & $41.7 \pm 5.76 a$ & $111.11 / \mathrm{C}$ \\
\hline C. carbonica $30 \mathrm{CH}$ & $95.4 \pm 0.27 \mathrm{a}$ & $50.8 \pm 2.95 a$ & $2.4 \pm 0.13 a$ & $45.2 \pm 6.84 a$ & $107.72 / C$ \\
\hline Kali iodatum $100 \mathrm{CH}$ & $93.4 \pm 1.10 \mathrm{a}$ & $44.2 \pm 3.35 b$ & $3.1 \pm 0.06 a$ & $27.2 \pm 1.22 b$ & $93.37 / \mathrm{C}$ \\
\hline Phosphorus 3CH & $94.3 \pm 1.26 a$ & $54.0 \pm 2.34 a$ & $3.0 \pm 0.11 \mathrm{a}$ & $37.5 \pm 4.48 a$ & $106.60 / C$ \\
\hline Silicea $30 \mathrm{CH}$ & $94.2 \pm 0.74 \mathrm{a}$ & $41.4 \pm 3.77 b$ & $2.4 \pm 0.11 \mathrm{a}$ & $25.3 \pm 2.51 b$ & $80.53 / C$ \\
\hline Staphysagria $6 \mathrm{CH}$ & $94.9 \pm 1.62 \mathrm{a}$ & $55.4 \pm 7.06 a$ & $2.3 \pm 0.24 a$ & $29.1 \pm 2.22 b$ & $84.62 / C$ \\
\hline Staphysagria $30 \mathrm{CH}$ & $93.8 \pm 1.26 \mathrm{a}$ & $42.2 \pm 5.02 b$ & $3.0 \pm 0.12 \mathrm{a}$ & $28.7 \pm 6.17 b$ & $93.66 / C$ \\
\hline Staphysagria $100 \mathrm{CH}$ & $93.2 \pm 1.10 \mathrm{a}$ & $43.6 \pm 7.64 b$ & $3.1 \pm 0.10 \mathrm{a}$ & $36.5 \pm 6.36 a$ & $105.97 / C$ \\
\hline S. frugiperda $30 \mathrm{CH}$ & $93.4 \pm 1.04 \mathrm{a}$ & $61.0 \pm 3.80 a$ & $3.0 \pm 0.36 a$ & $26.3 \pm 2.39 b$ & $90.57 / C$ \\
\hline Sulphur $100 \mathrm{CH}$ & $93.8 \pm 1.27 \mathrm{a}$ & $51.6 \pm 2.90 a$ & $3.0 \pm 0.30 a$ & $38.1 \pm 4.21 \mathrm{a}$ & 106.59/C \\
\hline Sulphur $200 \mathrm{CH}$ & $93.8 \pm 1.59 \mathrm{a}$ & $35.6 \pm 4.99 b$ & $3.1 \pm 0.10 \mathrm{a}$ & $35.2 \pm 1.82 \mathrm{a}$ & $104.58 / C$ \\
\hline T. occidentalis $200 \mathrm{CH}$ & $94.7 \pm 0.87 a$ & $50.8 \pm 4.25 a$ & $3.0 \pm 0.16 a$ & $25.6 \pm 3.94 b$ & $90.16 / C$ \\
\hline C.V. (\%) & 2.13 & 16.04 & 5.20 & 22.33 & - \\
\hline Factor $\mathrm{F}$ & 0.82 & 4.80 & 1.04 & 3.71 & - \\
\hline
\end{tabular}

Means ( \pm SE) followed by the same letter in the column for each product tested does not differ by the Scott-Knott test at $5 \%$ significance. T values, according to Rossi-ZALAF et al. (2008) between 0 and 41 = toxic (T); between 42 and 66 = Moderately toxic (MT); greater than $66=$ compatible (C). CFU: colony forming units. 
This increase in CFU is a trend already observed by other authors in analyses of NP (commercial products, aqueous and alcoholic plant extracts) and biological parameters of $M$. anisopliae, which can likely be attributed to the degradation and utilization of substances present in the composition of products tested and may have been used as nutrients by the fungus (Formentini et al., 2013; Mamprim et al., 2013).

In contrast, in the dilutions whose homeopathic solutions were used in the tests (with the exception of medicine Phosphorus $03 \mathrm{CH}$ ), the probability of having material from the original substance in solution is very remote, since from the twelfth dilution (1/100) it exceeds the number of Avogadro (6.02 $\times$ $\left.10^{23}\right)$, leaving only the information of the original substance (Davenas et al., 1988). Thus, according to the homeopathy principles, the homeopathic drug action is the result of the stimulus of the information in this diluted medication. Thus, in the absence of matter, the possibility of the presence of active ingredients in homeopathic solutions may have caused the increased CFU in the present work is discarded, still not known to the mechanism of action of homeopathy on the organism at the cell level (BonATo et al. 2012).

Furthermore, the informational presence of $S$. frugiperda in homeopathic preparation may have been based on the homeopathy principles, a factor to stimulate the growth of fungus that is pathogenic to this insect (CARNEIro et al., 2008).

It is noteworthy that in the few studies verifying the action of homeopathic solutions on the pathogenic fungi, the effect on the number of CFU is not evaluated (ToLEDO, 2009; Modolon, 2010), making it difficult to compare with this class of products.

The lack of effect on vegetative growth was confirmed in the diameter of colonies, which did not differ statistically among products and between them and the control.

However, the drugs Sulphur, Silicea terra, Staphysagria, Phosphorus and Kali iodatum, when incorporated into the PDA culture medium, reduced the vegetative growth of $A$. solani (Toledo, 2009). Similarly, Arsenicum album at Staphysagria at the dynamization $6,12,25,30,50,60,80$ and $100 \mathrm{CH}$ promoted reduction in vegetative growth of $A$. solani when applied to the fungus inoculated on the PDA culture medium (Modolon, 2010). In such cases, variations may be caused by concentrations and especially by the difference between fungal species involved.

Conidia production was stimulated by drugs Arsenicum album $24 \mathrm{CH}$, Calcarea carbonica $30 \mathrm{CH}$, Phosphorus $3 \mathrm{CH}$, Staphysagria $100 \mathrm{CH}$ and Sulphur 100 and $200 \mathrm{CH}$, and promoted significant increase when compared to control water (Table 3).

Under field conditions, the rust infestation (Phakopsora euvitis Ono) was reduced with homeopathic solutions of Silicea $30 \mathrm{CH}$ over $90 \%$, which proves the fact that homeopathic solutions have no broad spectrum action, i.e., in different fungi can cause different results (BONATO et al., 2006).
Regarding toxicity, according to the biological index proposed by Rossi-ZALaF et al. (2008), all homeopathic treatments were compatible to the fungus $M$. anisopliae with toxicity values above 80 (values greater than $\mathrm{T}=66$ compatible).

The absence of similar studies makes it difficult to discuss the results of this parameter, but, based on the absence of negative interaction of homeopathic solutions tested in this work with all biological parameters of $M$. anisopliae, it may be considered that the combined use in field is safe, given the conditions in the laboratory being of maximum exposure among drugs and fungus and field (Alves et al., 1998a).

\section{Action of homeopathic treatments on the insecticidal activity of M. anisopliae on D. saccharalis}

The $D$. saccharalis mortality by the fungus was not affected by the presence of homeopathic drugs in the culture medium by comparing the treatment containing the fungus produced in culture medium treated with water only (control fungi). Mortality confirmed was between 78 and 98\% (Table 4).

The lack of effect of homeopathic treatments on the insecticidal activity of $M$. anisopliae reflects, besides the absence of effects on the above parameters and also because these drugs at such dilutions may not have specific action on the fungus $M$. anisopliae able to inhibit some step of its metabolism

Table 4. Mortality confirmed ( \pm SE) of Diatraea saccharalis larvae undergoing homeopathic products and the fungus Metarhizium anisopliae (UNIOESTE 22) multiplied in amid ME + homeopathic medicines $\left(26 \pm 1^{\circ} \mathrm{C}\right.$ and $12 \mathrm{~h}$ photoperiod).

\begin{tabular}{lc} 
Treatment & $\begin{array}{c}\text { Confirmed } \\
\text { mortality (\%) }\end{array}$ \\
\hline Control & $00.0 \pm 0.00 \mathrm{~b}$ \\
\hline Hydroalcoholic solution (O.1\%) & $00.0 \pm 0.00 \mathrm{~b}$ \\
\hline M. anisopliae & $91.6 \pm 7.28 \mathrm{a}$ \\
\hline M. anisopliae + Arsenicum album 24CH & $96.6 \pm 3.84 \mathrm{a}$ \\
\hline M. anisopliae + Calcarea carbonica 30CH & $96.6 \pm 2.22 \mathrm{a}$ \\
\hline M. anisopliae + Kali iodatum 100CH & $94.7 \pm 3.92 \mathrm{a}$ \\
\hline M. anisopliae + Phosphorus $03 \mathrm{CH}$ & $91.6 \pm 4.84 \mathrm{a}$ \\
\hline M. anisopliae + Silicea 30CH & $86.6 \pm 3.14 \mathrm{a}$ \\
\hline M. anisopliae + Staphysagria 6CH & $78.3 \pm 8.53 \mathrm{a}$ \\
\hline M. anisopliae + Staphysagria 30CH & $95.0 \pm 3.68 \mathrm{a}$ \\
\hline M. anisopliae + Staphysagria 100CH & $90.0 \pm 6.66 \mathrm{a}$ \\
\hline M. anisopliae + Spodoptera frugiperda 30CH & $96.5 \pm 2.30 \mathrm{a}$ \\
\hline M. anisopliae + Sulphur 100CH & $88.3 \pm 6.57 \mathrm{a}$ \\
\hline M. anisopliae + Sulphur 200CH & $90.0 \pm 2.22 \mathrm{a}$ \\
\hline M. anisopliae + Thuya occidentalis 200CH & $98.3 \pm 1.92 \mathrm{a}$ \\
\hline C.V. (\%) & 13.30 \\
\hline Factor F & 69.18 \\
\hline
\end{tabular}

Means $( \pm$ SE) followed by the same letter in the column for each nature does not differ by the Scott-Knott test at $5 \%$ significance. 
to influence its action on $D$. saccharalis, such as synthesis of enzymes or toxins, important on the insecticidal activity of this fungal species (Alves et al., 1998a; Freimoiser et al., 2005).

In the literature, studies on interaction, either SP or NP and entomopathogenic fungi have not been focused on the effects on the insecticidal activity of the fungus, which makes difficult the full understanding of the interactions that these agents can promote to the insect, since currently in several crops products with different purposes are being applied in combination, as a way to reduce costs and manpower.
It is also important to note that the non-interference of homeopathic treatments on the pathogenicity of $M$. anisopliae is very positive for the conservation of the natural enemy in the environment, thus becoming inoculum for probable epizooties (Alves; Lecuona, 1998).

\section{ACKNOWLEDGEMENTS}

To the CNPq and CAPES for grants and funding the research.

\section{REFERENCES}

ALMEIDA, A.A.; GALVÃO, J.C.C.; CASALI, V.W.D. Tratamentos homeopáticos e densidade populacional de Spodoptera frugiperda (J.E. Smith, 1979) (Lepidoptera: Noctuidae) em plantas de milho no campo. Revista Brasileira de Milho e Sorgo, v.2, n.2, p. 1-8, 2003.

ALVES, S.B. Fungos entomopatogênicos. In: Controle microbiano de insetos. 2.ed. Piracicaba: FEALQ, 1998. cap. 1 1, p. 289-381.

ALVES, L.F.A.; NEVES, P.M.O.; FARIA, M.R. Recomendações para utilização de fungos entomopatogênicos no controle de pragas. Piracicaba: CP 2, 2010. 52p.

ALVES, S.B.; ALMEIDA, J.E.M.; MOINO JUNIOR, A. Produtos fitossanitários e entomopatógenos. In: ALVES, S.B. (Ed.). Controle microbiano de insetos. 2.ed. Piracicaba: FEALQ, 1998a. cap.8, p. 217-238.

ALVES, S.B.; FERRAZ, L.C.C.B.; CASTELLO BRANCO JUNIOR, A. Chaves para a identificação de patógenos de insetos. In ALVES, S.B. (Ed.), Controle microbiano de insetos. Piracicaba, FEALQ: 1998b. cap.36, p.1039-1074.

ALVES, S.B.; LECUONA, R.E. Epizootologia aplicada ao controle microbiano. In: ALVES, S.B. (Ed.). Controle microbiano de insetos. 2.ed. Piracicaba: FEALQ, 1998. cap. 5, p.97-169.

ALVES, S.B.; LOPES, R.B. Controle microbiano de pragas na América Latina: Avanços e desafios. Piracicaba: FEALQ, 2008. 414 p.

ANDRADE, F.M.C. Homeopatia no crescimento e produção de cumarina em chambá Justicia pectoralis Jacq. 2000. $124 \mathrm{f}$. Dissertação (Mestrado) - Universidade Federal de Viçosa, Viçosa, 2000.

BONATO, C.M.; SOUZA, A.F.; COLLET, M.A. Controle da ferrugem (Phakopsora euvitis Ono) em videira pela aplicação de soluções homeopáticas. In: ENCONTRO DA CULTURA HOMEOPÁTICA, 16, SIMPÓSIO DO GIRI, XX., 2006, São Paulo, SP. Resumos. São Paulo: 2006. p.52.

BONATO, C.M.; SOUZA, A.F.; OLIVEIRA, L.C.; TOLEDO, M.V.; PERES, P.G.P.; GRISA. S.; SAAR, V.V. Homeopatia simples: alternativas para a agricultura familiar. Marechal Cândido Rondon: Gráfica Líder, 2012. 36p.
BRASIL. Farmacopéia Homeopática Brasileira. São Paulo: Atheneu, 1997. 118p.

BRASIL. Consulta de produtos formulados. Ministério da Agricultura, Pecuária e Abastecimento. Brasília: MAPA, 2013. Disponível em: http://agrofit.agricultura.gov.br/agrofit_cons/principal_agrofit_ cons. Acesso em: 20 jun. 2013.

BRUNINI, C.; ARENALES, M.C. Staphysagria. In: BRUNINI, C.; SAMPAIO, C. (Ed.). Matéria médica homeopática. v.3. São Paulo: Mythus, 1993. p.165-180.

CARNEIRO, A.A.; GOMES, E.A.; GUIMARÃES, C.T; FERNANDES, F.T.; CARNEIRO, N.P.; CRUZ, I. Molecular characterization and pathogenicity of isolates of Beauveria spp. to fall armyworm. Pesquisa Agropecuária Brasileira, v.43, p.513-520, 2008.

CASTRO, D.M. Preparações homeopáticas em plantas de cenoura, beterraba, campim-limão e chambá. 2002. 240f. Tese (Doutorado - Fitotecnia) - Universidade Federal de Viçosa, Viçosa, 2002. Disponível em: < http://alexandria.cpd.ufv. br:8000/teses/fitotecnia/2002/174970f.pdf >. Acesso em: 15 jun. 2013.

CASALI, V.W.D.; ANDRADE, F.M.C.; DUARTE, E.S.M. Acologia de Altas Diluições. Viçosa: Departamento de Fitotecnia da Universidade Federal de Viçosa, 2009. 537p.

DAVENAS, E.; BEAUVAIS, F.; AMRA, J.; OBERBAUM, M.; ROBINZON, T.B.; MIADONNA, A.T.; TEDESCHI, A.; POMERANZ, B.; FORTNER, P.; BELON, P.; SAINTE-LAUDY, J.; POITEVIN, B.; BENVENISTE, J. Human basophil degranulation triggered by very dilute antiserum against IgE. Nature, Reino Unido, v.333, n.30, p.816-818, 1998.

DUARTE, E.S.M. Crescimento e teor de óleo essencial em plantas de Eucalyptus citriodora e Eucalyptus globulus tratadas com homeopatia. 2007. 188f. Tese (Doutorado em Fitotecnia) Universidade Federal de Viçosa, Viçosa, 2007.

FARIA, M.R.; WRAIGHT, S.P. Mycoinsecticides and Mycoacaricides: A comprehensive list with worldwide coverage and international classification of formulation types. Biological Control, Orlando, v.43, p.237-256, 2007. 
FERREIRA, D.F. Sisvar: A computer statistical analysis system. Ciência e Agrotecnologia, Lavras, v.35, n.6, p.1039-1042, 2011.

FORMENTINI, M.A.; ALVES, L.F.A.; MAMPRIM, A.P.; PINTO, F.G.S. In vitro assay of alternative phytossanitary products and plant extracts on Metarhizium anisopliae (Metsch.) Sorok. (Clavicipitaceae). Revista Brasileira de Agroecologia, Cruz Alta, no prelo, 2013.

FREIMOSER, F.M.; HU, G. ST LEGER, R. J. Variation in gene expression patterns as the insect pathogen Metarhizium anisopliae adapts to different host cuticles or nutrient deprivation in vitro. Microbiology, London, v. 151, p. 361-371, 2005.

KHANNA, K.K.; CHANDRA, S. Control of tomato fruit by Fusarium roseum with homeopathic drugs. Indian Phytopathology, India, v.29, p.269-272, 1976.

LEITE, L.G.; FILHO, A.B.; ALMEIDA, J.E.M.; ALVES, S.B. Produção de fungos entomopatogênicos. Ribeirão Preto: A.S. Pinto, 2003. 92p.

MAMPRIM, A.P.; ALVES, L.F.A.; PINTO, F.G.S.; FORMENTINI, M.A.; MARTINS, C.C.; BONINI, A.K. Efeito de defensivos agrícolas naturais e extratos vegetais sobre parâmetros biológicos de Metarhizium anisopliae (Metsch.) Sorok. Semina: Ciências Agrárias, Londrina, v.35, n.1. 2013.

MARQUES, R.P.; MONTEIRO, A.C.; PEREIRA, G.T. Crescimento, esporulação e viabilidade de fungos entomopatogênicos em meios contendo diferentes concentrações de óleo de Nim (Azadirachta indica). Ciência Rural, Santa Maria, v.34, n.6, p.1675-1680, 2004.

MICHEREFF FILHO, M.; FARIA, M.; WRAIGHT, S.P.; SILVA, K.F.A. S. Micoinseticidas e micoacaricidas no Brasil: Como estamos após quatro décadas?. Arquivos do Instituto Biológico, São Paulo, v.76, n.4, p.769-779, 2009.

MODOLON, T.A. Preparados em altas diluições para o manejo fitossanitário e pós colheita do tomateiro. 2010. 79f. Dissertação
(Mestrado em Produção vegetal) - Universidade do Estado de Santa Catarina, Lages, 2010.

OLIVEIRA, D.G.P. Proposta de um protocolo para avaliação da viabilidade de conídios de fungos entomopatogênicos e determinação da proteção ao calor conferida a Beauveria bassiana e Metarhizium anisopliae pela formulação em óleo emocionável. 2009. $90 f$. Dissertação (Mestrado em Ciências) - Escola Superior de Agricultura Luiz de Queiroz, Piracicaba, 2009.

PARRA, J.R.P. Técnicas de criação de insetos para programa de controle biológico. Piracicaba: FEALQ, 1999. 137p.

ROSSI-ZALAF, L.S.; ALVES, S.B.; LOPES, R.B.; NETO, S.S.; TANZINI, M.R. Interação de microrganismos com outros agentes de controle de pragas e doenças. In: ALVES, S.B.; LOPES, R.B. (Ed). Controle microbiano de pragas na América Latina: avanços e desafios. Piracicaba, FEALQ, 2008. p.279-302.

RUPP, L.C.D.; BOFF, M.I.C.; BOTTON, M.; SANTOS, F.; BOFF, P. High dilution of Staphysagria and fruit fly biotherapics preparations to manage South American fruit fly, Anastrepha fraterculus, in organic peach orchards. Biological Agriculture \& Horticulture, London, v.28, n.1, p.41- 48, 2012.

SILVA, R.Z.; NEVES, P.M.O.J.; SANTORO, P.H. Técnicas e parâmetros utilizados nos estudos de compatibilidade entre fungos entomopatogênicos e produtos fitossanitários. Semina: Ciências Agrárias, Londrina, v.26, n.3, p.305-312, 2005.

SINHA KK; SINGH P. Homeopathic drugs inhibitors of growth and aflatoxin production by Aspergillus parasiticus. Indian Phytopathology, New Delhi, v.36, p. 356-357, 1983.

TOLEDO, M.V. Fungitoxicidade contra Alternaria solani, controle da pinta preta e efeito sobre o crescimento do tomateiro (Lycopersicum esculentum Mill) por medicamentos homeopáticos. 2009. $95 \mathrm{f}$. Dissertação (Mestrado em Agronomia) - Universidade do Oeste do Paraná, Marechal Cândido Rondon, 2009. 